HNF-SA-3179-FP

\title{
Condensation Induced Water Hammer Safety
}

M. A. Gintner

DynCorp

Date Published

March 1997

Prepared for the U.S. Department of Energy Assistant Secretary for Environmental Management

Project Hanford Management Contractor for the

U.S. Department of Energy under Contract DE-ACO6-96RL13200

Copyight Licanas By accoptence of this articlo, the publisher and/ar recipient acknowlodges the

U.S. Government's right to retain a nonexclusive, loyaity-free license in and to any copyright covering this paper.

Approved for public release; distribution is unlimited 
LEGAL DISCLAJMER

This report was prepared as an account of work sponsored by an agency of the United States Government. Neither the United States Government nor any agency thereof, nor any of their employees, nor any of their contractors, subcontractors or their employees, makes any warranty, express or implied, or assumes any legal tiability or responsibility for the accuracy, completeness, or any third party's use or the results of such use of any information, apparatus, product, or process disclosed, or represents that its use would not infringe privately owned rights. Reference herein to any specific commercial product, process, or service by trade name, trademark, manufacturer, or otherwise, does not necessarily constitute or imply its endorsement, recommendation, or favoring by the United States Government or any agency thereof or its contractors or subcontractors. The views and opinions of authors expressed herein do not necessarily state or reflect those of the United States Government of any agency thereof.

This repor has been reproduced from the best available copy.

Printed in the United States of America

DISCLM-2.CHP (t-91) 


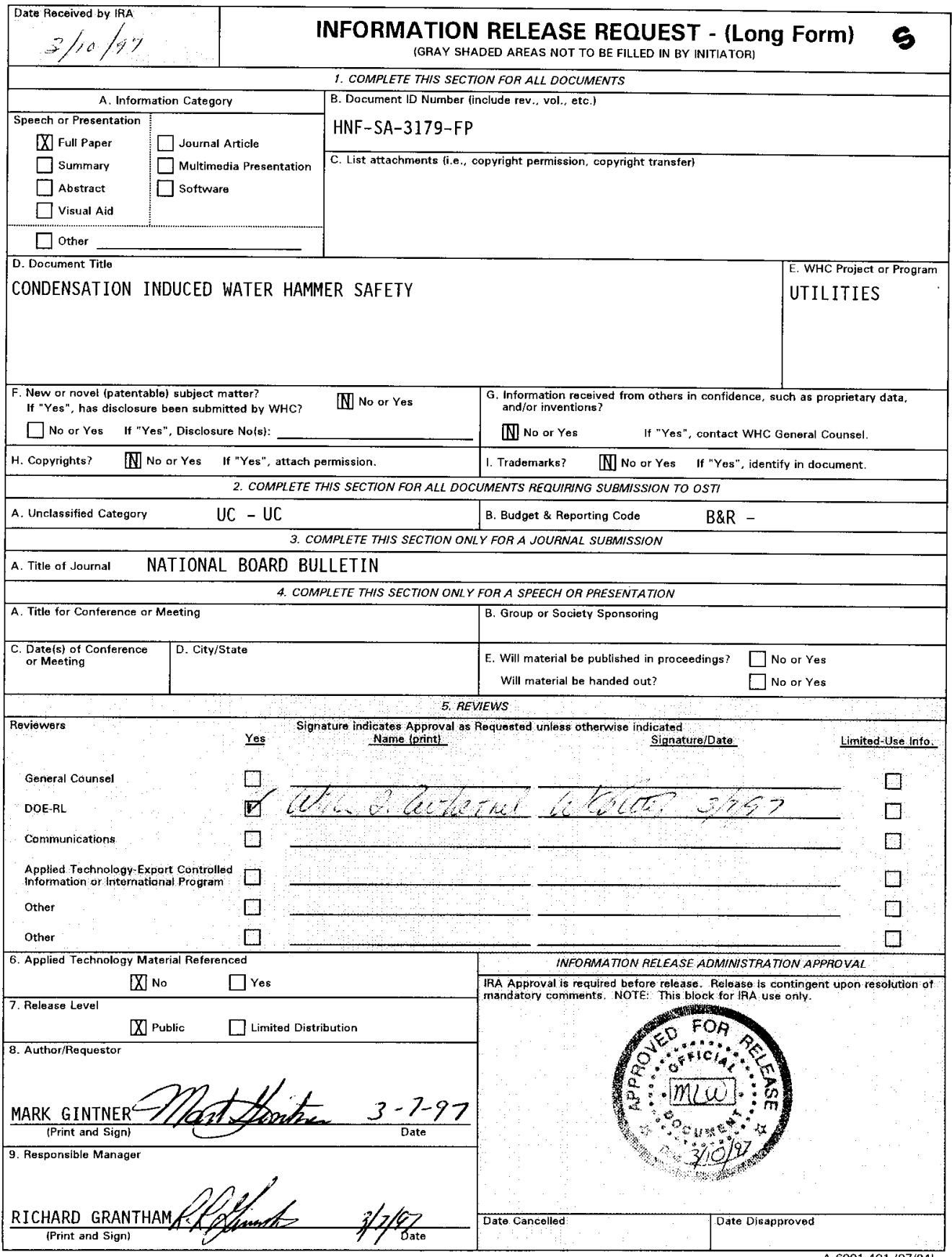


HNF-SA-3179-FP

Document ID Number

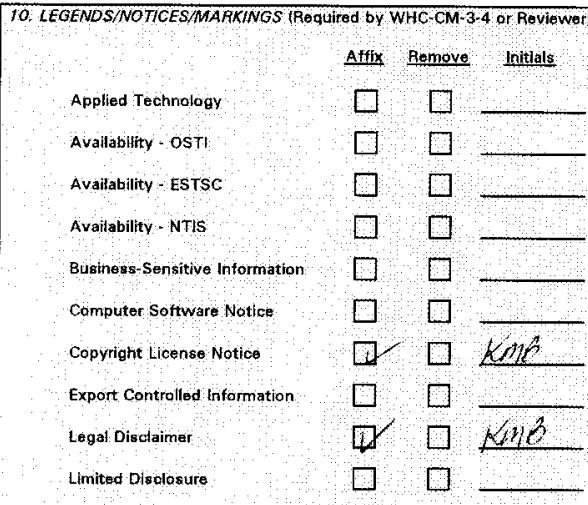

Rovlewer indicatos applicable markings to be affixed or removed

11. MANDATORY COMMENTS (List only mandatory comments hero: All other comments shall be made on the document and retumed to the author)

\section{Otficial Use Only}

Patent Status

Predocisional Information

Programmatic Notfes

Propifetary Information

Purpose and Utse

Thesis/Dissertation

Trademark Disclatamer

Otlier
Affix Remove fnitials

$\square \square$

$\square \quad \square$

$\square \quad \square$

$\square \square$

$\square, \square$

$\square \square$

$\square \quad \square$

$\square$

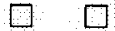

(n)




\section{INTRODUCTION}

Condensation induced water hammer events in piping systems can cause catastrophic steam system failures which can result in equipment damage, personal injury, and even death. As an industry, we have learned to become accustomed to the "banging" that we often hear in our steam piping systems, and complacent in our actions to prevent it. It is unfortunate that lives are lost needlessly, as this type of water hammer event is preventable if one only applies some basic principles when operating and maintaining their steam systems. At the U.S. Department of Energy's Hanford Site where I work, there was one such accident that occurred in 1993 which took the life of a former co-worker and friend of mine.

Hanford was established as part of the Manhattan Project during World War II. It is a 560 square mile complex located along the banks of the Columbia River in Southeastern Washington State. For almost 45 years, Hanford's mission was to produce weapons grade plutonium for our nations defense programs. Today, Hanford no longer produces plutonium, but is focused on site clean-up and economic diversification. Hanford still uses steam for heating and processing activities, utilizing over 20 miles of piping distribution systems similar to those found in industry. Although these aging systems are still sound, they cannot stand up to the extreme pressure pulses developed by a condensation induced water hammer.

\section{CONDENSATION INDUCED WATER HAMMER PHENOMENON}

A condensation induced water hammer (CIWH) is a phenomenon which occurs when steam is either allowed to enter into a piping system that contains water (condensate), or conversely when water is injected into a piping system that contains steam. The combination of the condensing action at the steam/water interface and the flow of steam over the water will cause waves to form. These

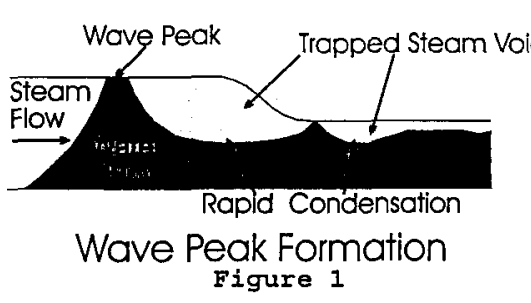
waves will grow until they reach the whole cross section of the pipe, which traps steam between the wave peaks as shown in Figure 1. Once the steam is trapped, rapid condensation takes place at the interface, which collapses the steam volume. These implosions coupled with the velocity of the steam flow, create incredible pressure pulses which can reach several thousand pounds pressure, and have catastrophic results.

\section{CASE STUDY - U3 PIT ACCIDENT - JUNE 7TH 1993}

Our introduction to the CIWH phenomena took place in what is known as the 300 Area of the Hanford Site. Steam Utilities personnel were going to reconfigure an existing valve lineup in preparation for a steam outage to a facility. 300 Area steam is supplied from a central powerhouse which has several export lines that form a looped stean system. This allows isolation of one facility without disnupting service to other facilities.

Steam pressure in the 300 Area is $125 \mathrm{psig}$, and the temperature is at saturation, or about $350^{\circ} \mathrm{F}$. A large portion of the steam lines in this system are underground, with valving stations located in pit areas. It was one such valving station that was the location of our accident - the U3 
Pit (see Figure 2). The U3 pit contains four valves. MSS-25 and MSS-27 are 8" steam supply valves from the looped powerhouse system, MSS-26 is a 4" steam isolation valve to a facility, and then there was one 6" valve that was blanked off for future expansion of the system.

The plan was to close MSS-27 so that maintenance could be conducted on that part of the system, and reroute steam through MSS-25. MSS-25 is normally opened, however, it was closed 8 months earlier for a steam outage. After that outage was completed, it was decided that MSS-25 would remain closed because of the hazards involved in re-opening it. First, it required entry into a confined space, second, there was a possibility that asbestos was present, and third, steam pits such as this typically exceed $140^{\circ} \mathrm{F}$. Steam however, was restored to the entire looped system after that outage, so that although closed, MSS-25 had pressure on both sides of the valve. Now, MSS-25 would have to be opened in order to maintain steam service to the facilities.

Around 7:00 o'clock on the evening of June 7th, the operations crew began the task of reconfiguring the system. A plant operator entered the U3 pit and unlocked MSS-25, and began to unseat the valve. The crew outside the pit entrance saw some condensate discharge from the steam trap (to a french drain), however, after a short time, it appeared to stop. The operator in the pit continued to open the valve, and a few moments later, there was a loud "bang", followed by the expulsion of steam, rock, and debris from the pit. Amazingly, the operator was able to exit the pit on his own adrenaline, but he was so severely burned (internal and external) that he died a few days later from his injuries.

Lets look at what actually happened here. Although it was understood that there would be some condensate accumulated in front of MSS25 , it was not known how much condensate was actually present. The pipe upstream of MSS-25 was 840 feet long, and was sloped downward approximately 13 feet towards the U3 pit, and it was calculated that the 8 "line was filled with approximately 1,500 gallons of subcooled $\left(55^{\circ} \mathrm{F}\right)$ condensate. As the operator began to open up the valve, the condensate moved up the vertical pipe until it reached the horizontal section, where it flowed both concurrently and countercurrently with the steam flow (see Figure 3). This action coupled with the rapid condensation of the steam

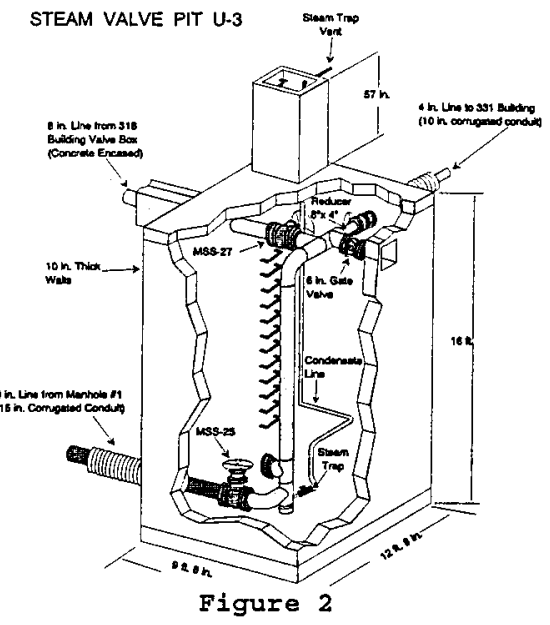
at the steam/water interface resulted in a violent CIWH. Pressure pulses estimated at $2,300 \mathrm{lbf} / \mathrm{in}^{2}$ 
found the weakest link in the system, which was the 6 inch cast iron valved that was blanked off (see Figure 4). The valve separated at the flange, and the resulting steam flow excavated a large hole adjacent to the pit (see Figure 5).

\section{AN ISOLATED INCIDENT?}

Our accident in 1993 at Hanford was our first experience with a CIWH phenomenon of this magnitude. When we attempted to obtain more information, we found that it was both difficult to get, or in most cases, non-existent. Why is this?

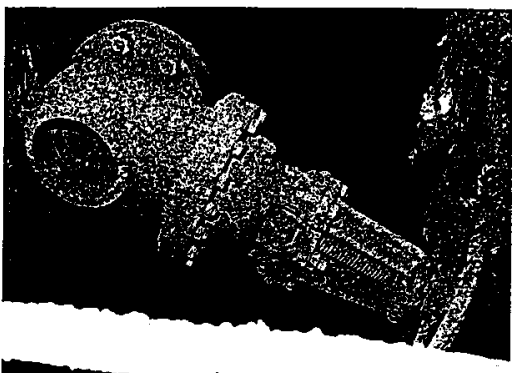

Figure 4 Those who have suffered serious water hammer events in the past are reluctant to talk about it let alone write about it, because of the sensitivity of the subject and the legal issues and implications. Today however, due to improved networking within our industry, information on CIWH and it's prevention is available to those who need it or want it. However, this information doesn't always reach those who need it most - our steam systems operators. The following examples illustrate this point.

In October of 1986, there was a major CIWH accident at the U.S. Department of Energy's Brookhaven National Laboratory. The crew was involved in placing a newly constructed steam line into service. Due to a combination of poor procedures and training, plus installation of an improperly sized steam trap, a CIWH was experienced when workers attempted to drain the accumulated condensate from the pressurized steam system. Four workman were injured in the accident, two of them fatally. Investigations were conducted, and reports were written, but few outside of Brookhaven ever saw it.

In August of 1989, less than a hundred miles from Brookhaven, in a place called Gramercy Park, New York, Con-Edison workers, using reachrods, were placing a steam system back into service which had been down for only 8 hours. A catastrophic CIWH occurred which blew out an expansion joint. They had failed to remove the accumulated condensate in the piping system before they opened the $20^{\prime \prime}$ valve on the 185 psig steam system. Two workers and one pedestrian were killed in the explosion. A short time later a video tape was produced which clearly explained the water hammer accident and how it could have been prevented. Again, few steam system workers outside of Con Edison ever saw this informative tape. Workers like Jack Smith.

In June, 1991, at a Georgia campus hospital, a fellow by the name of Jack Smith was restoring a looped 85 psig steam system to service. Jack had probably performed this task several times in the past and maybe he even experienced minor water hammers because the system had been modified earlier so that accumulated condensate could not be fully drained from the system. When Jack opened up the 8 inch valve, steam bubbles moved under the valve seat, and began collapsing violently with the water on the other side of the valve and a catastrophic CIWH occurred. They found Jack's body at the bottom of the pit, under 2 and $1 / 2$ feet of hot condensate, with the fractured valve body above him. An article was published in "Heating, Piping, and Air Conditioning", where the author, after describing the accident, asks the question; "Could this happen again?" He answers "yes", and then in June of 1993, we had our accident at Hanford which resulted in one fatality. 


\section{LESSONS LEARNED}

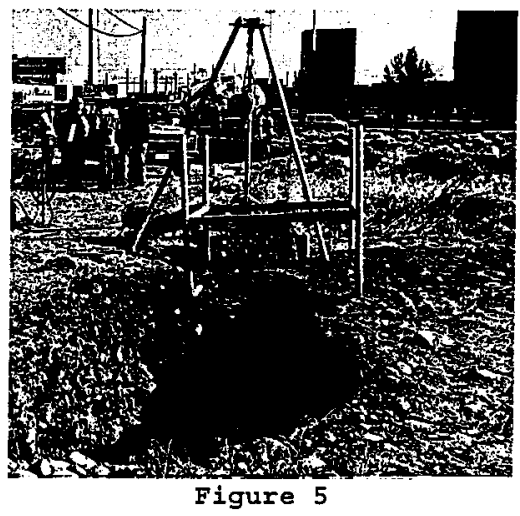

So what have we learned from these and other CIWH accidents? First, condensation induced water hammer is potentially fatal. Secondly, CIWH's in a piping system is not acceptable and is preventable. Third, steam trap sizing, operation, and maintenance play an important roll in the prevention of a CIWH. Finally, we learned that you cannot safely drain accumulated condensate from a charged steam system without risking a CIWH. Our corrective actions required us to find a way to get our workers to focus on preventing a water hammer BEFORE they ever put their hand on a valve wheel. We provided this focus in what we call the "Safety Principle" which states: "Steam and water can not be safely mixed in a piping system without risking Condensate Induced Water Hammer, Do not mix steam with water either by injecting water into a steam system or steam into a system that includes water (condensate). Condensate should be assumed to be in all low points and dead legs until proven otherwise." In order to reinforce the philosophy behind the safety principle, we provided several recommendations:

Engineers need to inspect their steam piping systems to ensure that there are sufficient traps and blowdowns to handle excess condensate generated during start-up and for normal operation.

- Operators and maintenance workers need to walk down their systems to ensure that traps are working properly and repair or replace defective traps.

- Using the method of "cracking" open a steam valve to remove excess condensate, will not protect you from a condensation induced water hammer.

- Valves in pipe lines which lack properly positioned steam traps should remain open at all times or preferably should be removed from the piping system. Otherwise, install traps at these locations.

- Using reach rods (extension linkage) is a good practice, but will not aiways protect you from the forces of a water hammer event.

- Steam piping systems should be inspected for sagging. Where necessary, install steam traps at these locations, or repair the sagging.

- Check and repair piping insulation. It will save energy, and reduce the accumulation of excess condensation in the piping system.

- Activation of cold piping should be performed slowly (using bypass valves if available) at reduced pressure, with bleedvalves (Mudlegs) continuously open until the piping reaches system pressures and temperatures.

- Placement of blowdown valves before and after a vertical rise is required to prevent possible condensate accumulation.

These recommendations should be followed regardless of piping size. Do not exclude small pipe sizes without an appropriate analysis.

- Finally, and I believe most importantly, improperly designed steam systems should not have the incorrect features overcome by operational methods. Sy'stems must have their incorrect features corrected. 


\section{CONCLUSION}

There is a time bomb out there ticking in our Nations steam systems today. Where or when it will go off again is difficult to say. We only know that if we continue the practice of mixing steam and water (condensate) in our piping distribution systems, it will happen again. We are however, beginning to see some progress in our efforts to raise awareness. At Hanford's Steam Utilities, we have not experienced a CIWH event for almost three years, and we routinely place miles of steam piping systems in and out of service. Industry is awakening also. We have received calls from dozens of Utilities, Universities, and other industrial users of steam, telling us about their water hammers, and wanting information and/or training on how to prevent them.

I have had the opportunity and privilege to take this message out across the United States. I have found that in general, steam system workers including engineers, planners, operators, maintenance personnel, and management alike are eager to learn, but have never been given the opportunity. Very few were aware of the potentially destructive power of this phenomenon and most had never heard of the accidents discussed in this article. But as I listen to them describe some of the events that they have experienced in they're own plants, it becomes apparent that we have hundreds if not thousands of CIWH events each year in this country. Most just result in banging in the piping systems, a few result in more serious accidents. The only way to eliminate this type of catastrophic event from happening again, is by training and educating our workforce of the potential hazards of a CIWH, and to maintain our steam systems to ensure they are sound and capable of draining all of the water out. In just these few accidents that I described today, tens of millions of dollars have been spent in damages and corrective actions.

Our conclusion is simple. Condensation induced water hammers are fatally serious. They should never be acceptable in our piping systems, and they are preventable when basic operational and engineering principles are applied. 